\title{
Traditional lecture versus PBL tutorials in Dental students' knowledge acquisition
}

\author{
Neiandro dos Santos Galvão*; Matheus Lima Oliveira**; Francine Kühl Panzarella***; \\ Ricardo Raitz***; José Luiz Cintra Junqueira****
}

* PhD student, Dental Radiology Graduate Program, Faculdade de Odontologia de Piracicaba, FOP/UNICAMP

** Professor, Departament of Oral Diagnosis, Faculdade de Odontologia de Piracicaba, FOP/UNICAMP

*** Professor, Departament of Oral Radiology, Centro de Pesquisas Odontológicas São Leopoldo Mandic, SLMANDIC

Received August 3, 2018. Approved December 23, 2018.

\begin{abstract}
Educators have currently recommended more dynamic models focused on the development of critical thinking, active learning and problem-solving. This prospective quantitative study aimed to compare the effect of two instructional formats - traditional lecture and problem-based learning (PBL) tutorials - on second-year dental students' knowledge in oral radiology. The students were randomly allocated into two groups: control group $n=64$ (traditional) and experimental group $n=65$ (PBL), both submitted to a course of oral radiology at different times - control group in the first half of 2015 and as the experimental group in the second half of the same year. In 2016, a test containing 30 questions in oral radiology was applied for students in both groups to evaluate their learning acquisition. The questions covered three domains: general principles, radiobiology/radioprotection, and technique/interpretation. The students' final score was compared between the two groups of teaching-learning methods by Mann-Whitney test. The significance level was set at $5 \%(\alpha=0.05)$. The mean values of students' final score of control and experimental groups were, respectively, 15.11 and 15.58 with no statistically significant difference between them $(p>0.05)$. Additionally, no statistically significant difference $(p>0.05)$ was observed between both groups even when the domains were analyzed separately. In conclusion, the PBL tutorials format did not have a direct influence on knowledge acquisition for these second-year dental students in oral radiology.
\end{abstract}

Descriptors: Teaching. Learning. Problem-Based Learning. Dentistry. Radiology.

\section{INTRODUCTION}

Although traditional method of teachinglearning can reach a large number of students and allow the transmission of more information in a short period, educators have currently recommended more dynamic models focused on 
the development of critical thinking, active learning, and problem solving ${ }^{1}$. This is particularly important to health professionals because they need to develop fundamental abilities such as to evaluate, organize and select the most appropriate practices based on scientific evidences ${ }^{2}$.

Among the active teaching-learning methods studied in the scientific literature, there is the problem-based learning (PBL), in which a problem serves as the motivation for learning ${ }^{3}$. Since the PBL is a student-centered approach, students are expected to actively identify the problem and manage to solve it based on their own perspective. This pedagogy was designed for small groups of students working together and interacting with each other and tutors to achieve understanding ${ }^{4,5}$.

Scientific evidence suggests that PBL does not adversely affect the acquisition of factual knowledge ${ }^{6-8}$ and has a positive effect on students' confidence in the practice of dentistry ${ }^{9,10}$. This method can also improve students' ability to apply their knowledge in clinical practice ${ }^{11-13}$. However, the number of well-designed scientific studies that compare the effectiveness of PBL in relation to the traditional method is limited, and a deeper analysis of the results is needed ${ }^{14,15}$.

When associated with oral radiology, PBL has shown satisfactory results in a population in Taiwan ${ }^{16}$ and, recently, in Spain ${ }^{17}$. Considering the complex and multifactorial nature of the teachinglearning process, as the sociocultural context and personality traits of students ${ }^{18}$, this prospective quantitative study aimed to compare the effect of two instructional formats - traditional lecture and problem-based learning (PBL) tutorials - on second-year dental students' knowledge in Oral Radiology.

\section{MATERIALS AND METHODS}

The local institutional Human Research Ethics Committee (protocol \#1.117.143/2015) approved this prospective quasi-experimental and quantitative study. Initially, students attending the second year of the university's Dentistry course in São Lucas University Center were invited to participate in the research. The students were informed that the purpose of this study was to compare two instructional formats through the acquisition of knowledge in Oral Radiology.

The students who agreed to participate in the study were randomly allocated into two groups: control group $\mathrm{n}=64$ (traditional) and experimental group $\mathrm{n}=65$ (PBL), both submitted to a course of Oral Radiology at different times control group in the first half of 2015 and as the experimental group in the second half of the same year. Demographics of the participants were obtained to characterize the sample. Exclusion criteria were the students who had previously attended the oral radiology course.

The control group attended classes in the form of lectures with a professor making use of a multimedia projector. The experimental group was divided into seven groups of seven through ten students each, who followed the seven steps of $\mathrm{PBL}^{1}$ to solve the problems raised in each meeting. The students of both groups attended a course of 15 sessions of 2 hours each in a period of 6 months, and their progress was assessed according to the methodology of each teachinglearning method to comply with requirements of university, but this did not influence the present study (figure 1).

The same professional graduated in dentistry and post graduated in higher education methodology and oral radiology, and with five years of teaching experience, acted as the professor and tutor and conducted all the activities with both groups.

A validated test ${ }^{19}$ containing 30 questions in oral radiology was applied for students in both groups to evaluate their performance. Table 1 shows the test with the correct answers. 


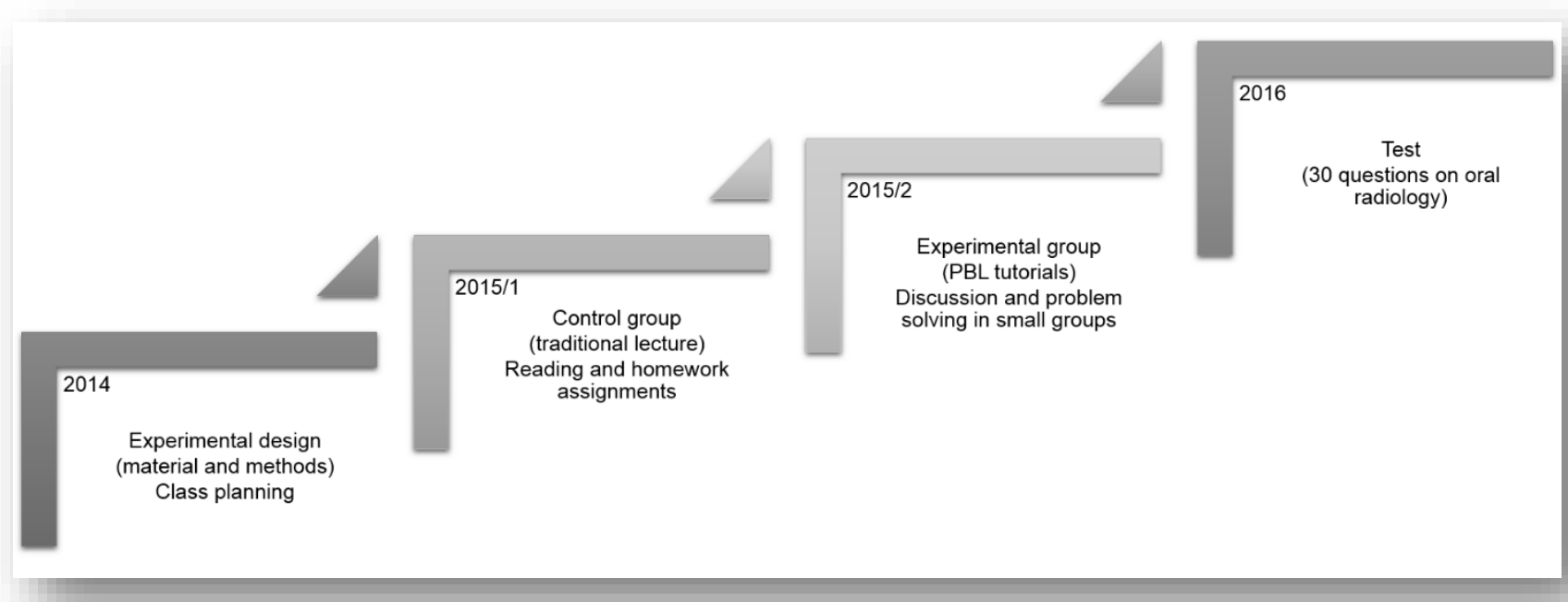

Figure 1. Experimental design of the control and experimental groups

The questions covered three domains general principles, radiobiology/radioprotection, and technique/interpretation - and could be answered with "True", "False", or "I don't know". The latter option was made available to prevent the students to give random responses by guessing the answers. At the end, the test had three questions to assess the level of the difficulty of the previously answered questions based on the Brazilian National Exam for the Assessment of Student Learning (ENADE) ${ }^{20}$.

The SPSS software version 22 (IBM Corp., Armonk, NY, USA) was used for statistical analysis. Data were dichotomized into correct and incorrect and the option "I don't know" was considered a wrong answer. The sum of the correct answers could range from zero to 30 and represented the students' final score, which was compared between the two groups of teaching-learning methods by Mann-Whitney test. The same test compared the students' partial score between the three domains of the questionnaire. The significance level was set at $5 \%(\alpha=0,05)$.

\section{RESULTS}

The overall response rate was $95.5 \%(\mathrm{n}=129)$ and the final sample comprised 64 students in the control group and 65 students in the experimental group. The sociodemographic survey (table 2) showed higher prevalence of female students $(69.7 \%)$ younger than 25 years old (86\%), with a household income ranging from 3.5 to 12 minimum wages $(50.4 \%)$.

Figure 2 shows the students' final score of control and experimental groups, in which the mean values ( \pm standard deviation) were, respectively, $15.11( \pm 3.78)$ and $15.58( \pm 2.86)$ with no statistically significant difference between them ( $>$ $>0.05)$. In addition, no statistically significant difference $(p>0.05)$ was observed between both groups even when the domains were analyzed separately (Figure 3$)$. The mean values ( \pm standard deviation) of each domain in the control and experimental groups were, respectively, 4.91 $( \pm 1.42)$ and $4.74( \pm 1.52)$ for general principles, 4.91 $( \pm 1.65)$ and $5.12( \pm 1.22)$ for radiobiology/ radioprotection and $5.30( \pm 1.91)$ and $5.72( \pm 1.63)$ for technique/interpretation. 
Table 1. Performance evaluation test with the correct answers

\begin{tabular}{|c|c|}
\hline Question & Response \\
\hline \multicolumn{2}{|l|}{ General Principles } \\
\hline 1. X-rays are electromagnetic radiation. & True \\
\hline 2. During examination, the x-ray operator must protect himself from the reflected rays. & False \\
\hline 3. The $x$-ray machine must be turned off when not in use to avoid inadequate $x$-ray emission. & False \\
\hline 4. It takes 5 seconds after an exposure to scatter radiation be dissipated. & False \\
\hline 5. It is not possible to generate $\mathrm{x}$-rays without power supply. & True \\
\hline $\begin{array}{l}\text { 6. The oil in the tube head is heated when the x-ray machine is turned on, even if no exposure } \\
\text { is performed. }\end{array}$ & False \\
\hline 7. The room must be immediately isolated if an $\mathrm{x}$-ray tube is broken. & False \\
\hline 8. A radiograph fixed for 15 seconds is adequate for diagnosis. & False \\
\hline 9. Covering the processing solutions can extend their lifespan. & True \\
\hline 10. Rinse stops the action of the developer in manual processing. & False \\
\hline \multicolumn{2}{|l|}{ Radiobiology/Radioprotection } \\
\hline $\begin{array}{l}\text { 11. Routine radiographic examination with a six-month interval cannot cause stochastic } \\
\text { biological effects. }\end{array}$ & False \\
\hline $\begin{array}{l}\text { 12. Radiographic examination in pregnant women must be performed only in the second } \\
\text { trimester of pregnancy to reduce the chance of deleterious effects. }\end{array}$ & True \\
\hline $\begin{array}{l}\text { 13. Protecting gonads from } x \text {-rays is not necessary because dental radiographs are taken in } \\
\text { the head and neck region. }\end{array}$ & True \\
\hline 14. All human tissues have the same radiosensitivity. & False \\
\hline $\begin{array}{l}\text { 15. Whole body low-intensity-fractionated irradiation is more dangerous than high-intensity- } \\
\text { localized irradiation. }\end{array}$ & True \\
\hline $\begin{array}{l}\text { 16. X-ray operators have minimal chance of somatic effects if they correctly adopt the } \\
\text { radioprotection rules. }\end{array}$ & True \\
\hline 17. Barriers like lead walls are mandatory to ensure adequate protection for the operator. & False \\
\hline $\begin{array}{l}\text { 18. An adequate maintenance of the } x \text {-ray machine results in better productivity and } \\
\text { protection for both operator and patient. }\end{array}$ & True \\
\hline $\begin{array}{l}\text { 19. Parents should hold films in children's mouth if they do not cooperate during } \\
\text { examination. }\end{array}$ & True \\
\hline 20. Periapical radiographs are strictly indicated for children only in case of emergency. & False \\
\hline \multicolumn{2}{|l|}{ Technique/Interpretation } \\
\hline 21. Bite-wing radiographs are indicated to investigate dental decay. & True \\
\hline 22. Oclusal radiographs are indicated to investigate bucco-lingual bone expansion. & True \\
\hline 23. Panoramic radiographs are indicated to investigate incipient caries lesions. & False \\
\hline $\begin{array}{l}\text { 24. A full-mouth series (FMX) is indicated if many teeth are absent during physical } \\
\text { examination. }\end{array}$ & False \\
\hline $\begin{array}{l}\text { 25. An unerupted superior left-canine dislocated with the } \mathrm{x} \text {-ray tube in the Clark method. } \\
\text { Therefore, it is located in a palatal position. }\end{array}$ & True \\
\hline $\begin{array}{l}\text { 26. An elliptical radioluscence in the apex of vital lower pre-molars with intact lamina dura } \\
\text { probably refers to the mental foramen. }\end{array}$ & True \\
\hline $\begin{array}{l}\text { 27. A diffuse radiolucency in the mandibular body, inferior to lower molars, may indicate an } \\
\text { aggressive lesion named "Stafne bone defect". }\end{array}$ & False \\
\hline 28. Dental decay is radiographically detected since the onset. & False \\
\hline 29. Multilocular ameloblastoma has a ground-glass appearance. & False \\
\hline 30. Tooth displacement and bone expansion are typical of malignant lesions. & False \\
\hline
\end{tabular}

Adapted from De Azevedo-Vaz SL et al (2013). ${ }^{19}$ 
Table 2. Distribution of absolute and relative (\%) frequency of the sociodemographic data of control and experimental groups

\begin{tabular}{|c|c|c|c|c|}
\hline \multirow{2}{*}{ Variables } & & \multicolumn{2}{|c|}{ Teaching-Learning Method } & \multirow{2}{*}{ Total } \\
\hline & & Control & Experimental & \\
\hline \multirow{2}{*}{ Sex } & Male & $19(29.6)$ & $20(30.7)$ & $39(30.3)$ \\
\hline & Female & $45(70.4)$ & $45(69.3)$ & $90(69.7)$ \\
\hline \multirow{2}{*}{ Age (years) } & $\leq 24$ & $54(84.4)$ & $57(87.7)$ & $111(86.0)$ \\
\hline & $>24$ & $10(15.6)$ & $8(12.3)$ & $18(14.0)$ \\
\hline \multirow{6}{*}{$\begin{array}{l}\text { Household } \\
\text { income }\end{array}$} & Up to $2 \mathrm{MW}$ & $5(7.9)$ & $4(6.1)$ & $9(7.0)$ \\
\hline & $\begin{array}{c}\text { From } 2 \text { to } 3.5 \\
\text { MW }\end{array}$ & $19(29.7)$ & $9(13.8)$ & $28(21.7)$ \\
\hline & $\begin{array}{c}\text { From } 3.5 \text { to } 6 \\
\text { MW }\end{array}$ & $12(18.7)$ & $20(30.8)$ & $32(24.8)$ \\
\hline & $\begin{array}{c}\text { From } 6 \text { to } 12 \\
\text { MW }\end{array}$ & $17(26.5)$ & $16(24.6)$ & $33(25.6)$ \\
\hline & Above 12 & $5(7.9)$ & $11(17.0)$ & $16(12.4)$ \\
\hline & Unknown & $6(9.3)$ & $5(7.7)$ & $11(8.5)$ \\
\hline Total per variable & & $64(100.0)$ & $65(100.0)$ & $129(100.0)$ \\
\hline
\end{tabular}

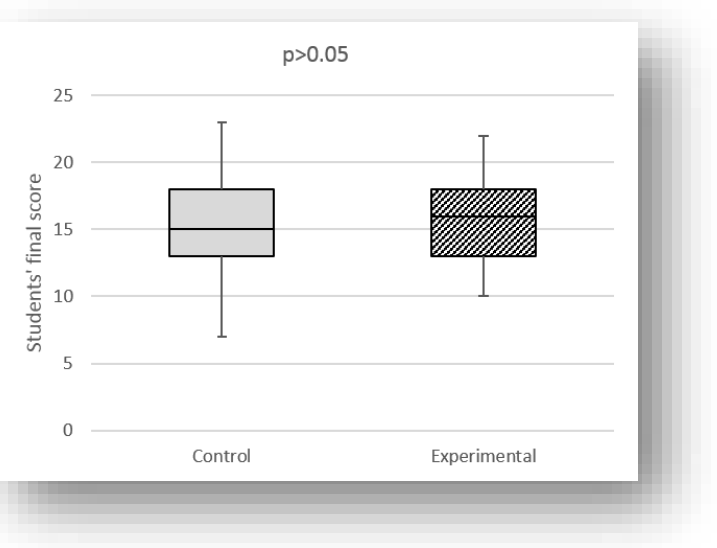

Figure 2. Box plot indicating the students' final score in the control and experimental groups

Regarding the level of difficulty of the questions, both groups agreed that the questions were of medium level $(74.4 \%)$ clear and objective $(90.6 \%)$. However, when asked about their own learning progress, the students had

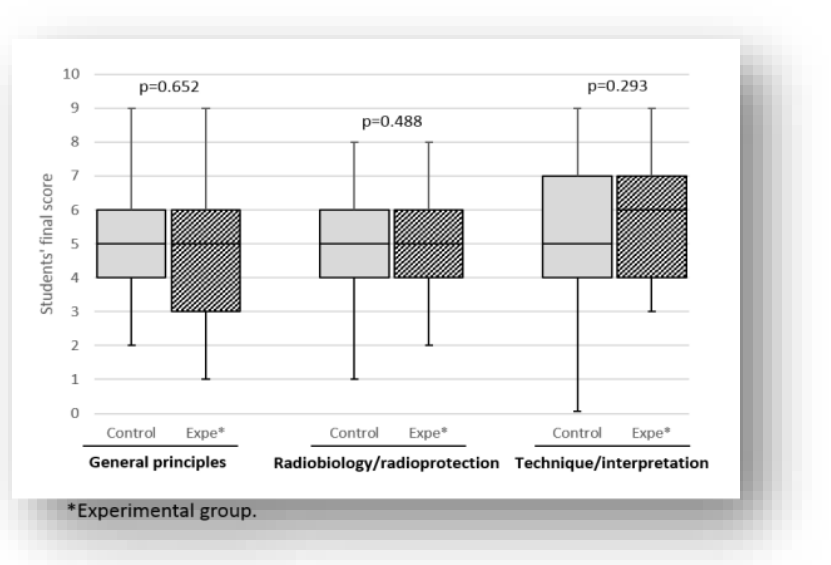

Figure 3. Box plot indicating the students' partial score of each domain in the control and experimental groups

different perceptions between groups. In the control group, most of them considered to have partially learned the lessons, while in the experimental group, most of the students believed to have actually learned the lessons. 


\section{DISCUSSION}

Considering that student learning and development is very complex and should be the main focus of teaching, educational research is of paramount importance in this process. When evaluating the cognitive performance of dental students who were submitted to different teaching-learning methods in the study of oral radiology, this study showed that the PBL does not differ from the traditional approach, even when the subject matter is separate in domains. Three domains were analyzed separately to investigate whether different learning objectives could interfere with students' performance. These findings are contrary to some studies ${ }^{22-24}$, in which the students who learned with the PBL method presented lower performance than those with the traditional method. Such disagreement is probably due to differences in the methodology and students' sociocultural characteristics.

This also reinforces the PBL method is an option that does not affect the cognitive performance of the student ${ }^{2,25-27}$. Demographic survey is critical because, besides characterizing the sample group, it may explain some of the results found in studies on teaching-learning process $^{18}$. The groups of this study were fairly homogeneous concerning the number of participants and characteristics such as sex, age and household income, which leads us to believe that the present results were not susceptible to sample characterization interference.

Due to the subjective nature of studies that evaluate only the students' perception of the teaching-learning method, an objective assessment was chosen ${ }^{14}$. However, behavioral factors associated with learning cannot be ignored given that studies have shown that despite the similar cognitive performance, students submitted to different teaching-learning methods may have different motivations and greater confidence to learn ${ }^{16,17,26}$.
In this study, dental students in the PBL group felt that they have learned great part of the content covered in the questionnaire. This finding is in agreement with other studies ${ }^{14,15}$ that showed that PBL students feel themselves better prepared to apply the knowledge acquired in relation to students who learned with the traditional methodology. Although the results obtained from the self-administered questionnaire may not necessarily reflect the actual professional performance, these data show that PBL has a positive effect on the confidence of students in the practice of dentistry ${ }^{11,12}$.

A recent systematic review on PBL in dental education ${ }^{7}$ found that only four scientific studies were of moderate methodological quality $^{6-8,14,27}$. All of them concluded that PBL was superior than traditional teaching-learning models with significant differences in some topics such as better performance in the American National Dental Board Examination ${ }^{6-}$ ${ }^{8}$, greater knowledge of science and health ${ }^{27}$, higher percentage of students graduating on time $^{7}$ and of graduates entering postdoctoral programs $^{28}$.

Two studies addressing the use of PBL in oral radiology, one being held in Taiwan ${ }^{16}$ and the other in Spain ${ }^{17}$, indicated satisfactory results in the correlation between this teaching-learning method and the course. However, the sociocultural and psychological backgrounds of the students from different countries should be considered $^{18}$. In Brazil ${ }^{29}$, the traditional teachinglearning method is still the most used and widespread approach. This situation may cause some discomfort common to any process of change and adaptation to students and be one of the reasons why, in this study, the PBL did not provide better performance to students, as observed in previous studies ${ }^{16,17}$.

The scientific comparison between teaching-learning methods is complex and has 
some inherent methodological limitations. However, the development of prospective matched case-control studies and tests to assess skills and competencies are likely to further contribute to the results on the use of PBL, which would encourage the educators to reflect on the use of active methodologies in educational institutions. Recent research ${ }^{18,30}$ indicates an integrated curriculum model with different teaching-learning methods to achieve better performance of students, considering the sociocultural and psychological profiles that are directly related to learning ${ }^{18}$.

\section{CONCLUSION}

The PBL tutorials format did not have a direct influence on knowledge acquisition for these second-year Brazilian dental students in Oral Radiology. The sociocultural and psychological backgrounds of students should be considered in futures studies on this topic.

\section{ABSTRACT \\ Método tradicional versus ABP na aprendizagem de acadêmicos de Odontologia}

Atualmente os educadores recomendam modelos mais dinâmicos focados no desenvolvimento do pensamento crítico, aprendizado ativo e solução de problemas. Este estudo quantitativo prospectivo teve como objetivo comparar o efeito de dois formatos de instrução - aulas tradicionais e aprendizagem baseada em problemas (ABP) sobre o conhecimento de estudantes de odontologia do segundo ano em Radiologia Odontológica. Os estudantes foram alocados aleatoriamente em dois grupos: grupo controle $n=64$ (tradicional) e grupo experimental $n=65$ (ABP), ambos submetidos a um curso de Radiologia Odontológica em diferentes momentos - grupo controle no primeiro semestre de 2015 e como grupo experimental no segundo semestre do mesmo ano. Em 2016, um teste contendo 30 questões em radiologia oral foi aplicado para estudantes de ambos os grupos avaliarem sua aquisição de aprendizagem. As questões abrangiam três domínios: princípios gerais, radiobiologia/radioproteção e técnica/ interpretação. $\mathrm{O}$ escore final dos estudantes foi comparado entre os dois grupos pelo teste de Mann-Whitney. O nível de significância foi estabelecido em $5 \%(\alpha=0,05)$. Os valores médios do escore final dos estudantes dos grupos controle e experimental foram, respectivamente, $15,11 \mathrm{e}$ 15,58 , sem diferença estatisticamente significativa entre eles ( $p>0,05)$. Além disso, não houve diferença estatisticamente significante $(p>0,05)$ entre os dois grupos, mesmo quando os domínios foram analisados separadamente. Em conclusão, o formato de tutoriais do $\mathrm{ABP}$ não teve influência direta na aquisição de conhecimento para esses estudantes.

Descritores: Ensino. Aprendizagem. Aprendizagem Baseada em Problemas. Odontologia. Radiologia.

\section{REFERENCES}

1. Davis BG. Tools for teaching. 2nd ed. Jossey-Bass: San Francisco, 2009.

2. Arias A, Scott R, Peters OA, McClain E, Gluskin AH. Educational outcomes of small-group discussion versus traditional lecture format in dental students' learning and skills acquisition. $J$ Dent Educ. 2016;80(4):459-65.

3. Hendricson WD, Andrieu SC, Chadwick DG, Chmar JE, Cole JR, George MC, et al. Educational strategies associated with development of problem-solving, critical thinking, and self-directed learning. J Dent Educ. 2006;70(9):925-36.

4. Lim WK. Dysfunctional problem-based learning curricula: resolving the problem. BMC Med Educ. 2012;12-89.

5. Townsend G, Winning T. Research in PBL: where to from here for dentistry? Eur J Dent Educ. 2011;15(3):193-8.

6. Sukotjo C, Thammasitboon $\mathrm{K}$, Howell $\mathrm{H}$, Karimbux N. Students' perceptions of prosthodontics in a PBL hybrid curriculum. 
J Prosthodont. 2008;7(6):495-501.

7. Susarla SM, Bergman AV, Howell TH, Karimbux NY. Problem-based learning and research at the Harvard School of Dental Medicine: a ten-year follow-up. J Dent Educ. 2004;68(1):71-6.

8. Shuler CF, Fincham AG. Comparative achievement on National Dental Board Examination Part I between dental students in problem-based learning and traditional educational tracks. J Dent Educ. 1998;62(9):666-70.

9. Rich SK, Keim RG, Shuler CF. Problembased learning versus a traditional educational methodology: a comparison of preclinical and clinical periodontics performance. J Dent Educ. 2005;69(6):64962.

10. Reich S, Simon JF, Ruedinger D, et al. Evaluation of two different teaching concepts in dentistry using computer technology. Adv Health Sci Educ Theory Pract. 2007;12(3):321-9.

11. Thammasitboon K, Sukotjo C, Howell H, Karimbux N. Problem-based learning at the Harvard School of Dental Medicine: selfassessment of performance in postdoctoral training. J Dent Educ. 2007;71(8):1080-9.

12. Greenwood LF, Townsend GC, Wetherell JD, Mullins GA. Self-perceived competence at graduation: a comparison of dental graduates from the Adelaide PBL curriculum and the Toronto traditional curriculum. Eur J Dent Educ. 1999;3(4):1538.

13. Walton JN, Clark DC, Glick N. An outcomes assessment of a hybrid-PBL course in treatment planning. J Dent Educ. 1997;61(4):361-7.

14. Bassir SH, Sadr-Eshkevari P, Amirikhorheh S, Karimbux, NY. Problem-based learning in dental education: A systematic review of the literature. J Dent Educ. 2014; 78(1):98109.

15. Ehsan E, Bassir SH, Eshkevari PS. Current state of the effectiveness of problembased learning in prosthodontics: a systematic review. J Dent Educ. 2014,78(5):723-34.

16. Chen SK, Chang HF, Chiang CP. Group learning factors in a problem-based course in oral radiology. Dentomaxillofac Radiol. 2001:30:84-87.

17. Palomares-Casado T. Enseñanza de la radiología y medicina física en el grado en odontología a través del aprendizaje basado en problemas. FEM. 2014;17(4):221-8.

18. Holen A, Manandhar K, Pant DS, Karmacharya BM, Olson LM, Koju R, et al. Medical students' preferences for problembased learning in relation to culture and personality: a multicultural study. Int J Med Educ. 2015;19(6):84-92.

19. de Azevedo-Vaz SL, Vasconcelos KF, Rovaris K, et al. A survey on dental undergraduates' knowledge of Oral Radiology. Braz J Oral Sci. 2013;12:109-13. 20. República Federativa de Brasil. Ministério da Educação. Questionário de percepção da prova. Exame Nacional de Desempenho dos Estudantes (ENADE). [Cited: January 26, 2017]. Available at: http://portal.inep.gov. br/web/guest/provas-e-gabaritos3.

21. Palácio do Planalto. Presidência da República Federativa do Brasil. [Cited: January 26, 2017]. Available at: http://www. planalto.gov.br/ccivil_03/_Ato20152018/20 15/Lei/L13152.

22. Vernon DT, Blake RL. Does problem-based learning work? A meta-analysis of evaluative research. Acad Med. 1993; 68(7):550-63.

23. Albanese MA, Mitchell S. Problem-based learning: a review of literature on its outcomes and implementation issues. Acad 
Med. 1993;68(1):52-81.

24. Dochy F, Segers M, Van den Bossche P, Gijbels D. Effects of problem-based learning: a meta-analysis. Learn Instr. 2003;13(5):533-68.

25. Zhang Y, Chen G, Fang X, et al. Problembased learning in oral and maxillofacial surgery education: the Shanghai hybrid. J Oral Maxillofac Surg. 2012;70(1):e7-e11.

26. Santos GN, Leite AF, Figueiredo PT, Pimentel NM, Flores-Mir C, de Melo NS, et al. Effectiveness of E-Learning in Oral Radiology education: a systematic review. J Dent Educ. 2016;80(9):1126-9.

27. Login GR, Ransil BJ, Meyer M, Truong NT, Donoff RB, McArdle PJ. Assessment of preclinical problem-based learning versus lecture-based learning. J Dent Educ. 1997;61(6):473-9.

28. Last KS, Appleton J, Stevenson H. Basic science knowledge of dental studens on conventional and problem-based learning
(PBL) courses at Liverpool. Eur J Dent Educ. 2001;5(4):148-54.

29. Galvão NS, de-Azevedo-Vaz SL, Oliveira ML. O método de aprendizagem baseada em problemas na disciplina de Radiologia Odontológica. Rev ABENO. 2016;16(4):728.

30. Elangovan S, Venugopalan SR, Srinivasan S, Karimbux NY, Weistroffer P, Allareddy $\mathrm{V}$. Integration of basic-clinical sciences, PBL, CBL, and IPE in US Dental Schools' Curricula and a proposed integrated curriculum model for the future. J Dent Educ. 2016;80(3):281-90.

\section{Correspondence to:}

Neiandro Santos Galvão

e-mail: neiandrogalvao@gmail.com

Faculdade de Odontologia de Piracicaba

Av. Limeira, 901

13414-903 Piracicaba/SP Brazil 